\title{
Motivators and Problems of Being a Global Migrant (Outsource) Soccer Labor in Turkey: A Preliminary Study
}

\author{
Zafer Çimen ${ }^{1}$, Ali Eraslan ${ }^{1}$, Halil Sarol ${ }^{2}$ \\ ${ }^{1}$ Gazi University, Faculty of Sport Science, Department of Sport Management, Ankara, Turkey \\ ${ }^{2}$ Kırıkkale University, Faculty of Sport Science, Department of Sport Management, Kırıkkale, Turkey \\ Correspondence: Zafer Çimen, Faculty of Sport Science, Department of Sport Management, Gazi University, Ankara, \\ Turkey.
}

Received: November 15, 2018

doi:10.11114/jets.v7i2.3770
Accepted: December 11, $2018 \quad$ Online Published: December 17, 2018

URL: https://doi.org/10.11114/jets.v7i2.3770

\begin{abstract}
The aim of this study was to reveal the motivators and problems of soccer players that pursue their professional careers in Turkey. In this qualitative research, convenience sampling and criterion sampling, which are kinds of nonrandom sampling methods was used to determine the participants. Eight male soccer players from the Genclerbirligi Soccer Team who were complied with the research criteria, voluntarily participated in the study. The demographic information form and semi-structured interview form were used as data collection tools. All interviews were recorded by audio and video recording devices. Data was analyzed by content analysis. The findings showed that; this study was supported the "mercenary", "ambiotis" and "nomadic cosmopolitan" items, which are in typologies that motivates athletes to migrate to a host country. In addition, language and cultural differences were the main problems for migrant athletes. In conclusion, this study demonstrated that besides the items in the typologies, "positive information" can facilitate the migration of athletes to a host country. Furthermore, it expressed the importance of inquiry on the cultural structure of the host country for migrant athletes, in order to minimize negative influences of problems.
\end{abstract}

Keywords: soccer, motivator, problems, migrant labour

\section{Introduction}

In today's world, the important and popular phenomenon term 'globalization' effects and changes the lives of people and societies. This also leads to the reshaping of all areas of human life for decades. For this reason, globalization is the most debatable term recently in social science, because of the significant change of the structure of modern society. One of the important areas that has been influenced by globalization is the structure of the labour force in the business world (Lee, 2010). Especially over the past few decades outsourcing has become a familiar concept in the general business community. Although the general business community has been using outsourcing as a corporate strategy for many years and, outsourcing has only recently surfaced in the sports industry or sport business (Burden \& $\mathrm{Li}, 2009$; Li \& Burden, 2002). Because the commercialization of the sport industry started later than the general business world.

The outsourcing of the labor force in the sports industry actualizes in two ways; athletes from the same nation and migrant athletes from other nations. With the commercialization and hence globalization of the sports industry, it is seen that outsourcing is oriented towards migrant or immigrant athletes especially within the most commercialized sports like soccer. For example, during the 2017-2018 season $77.3 \%$ of Manchester City, $73.9 \%$ of Lazio and $70.4 \%$ of Sevilla soccer team's players line up were composed of immigrant players (Armstrong, 2018). Even the national teams of westernized countries outsource their athletes. For example, nearly 18\% of Canadian Olympians since 1992 have been immigrant athletes (Schinke \& McGannon, 2014). Thus, more and more athletes and coaches freely transcend national borders and immigrant athletes growing in number. This situation is accepted as a ubiquitous and vivid signal of globalization in sports by Lee (2010).

However, the migration of athletes did not start with globalization. Its' roots go back to the modernization of sports with the introduction of rules, competition, and a governing body in the wake of industrialization in the 1860s (Agergaard, 2008). Globalization is not only playing an important role on enhancing the marketing efforts of sport organizations (Burden \& Li, 2009) and gaining the international visibility of countries. For example, migrant athletes were used by the NBA as a marketing strategy to attract the interest of basketball funs all over the world (Çimen et al., 2018). A 
similar tactic was used by Qatar to increase their international visibility (Campbell, 2010).

For this reason, globalization in the sports and sport labor migration has received considerable interest in literature and has produced a copious amounts of studies in the context of sport sociology (Lee, 2010), sport management (Thibault, 2009) and sport psychology (Schinke \& McGannon, 2014). Academicians also stated a variety of motivators (Magee \& Sugden, 2002; Maguire, 1996) and problems (Hay, 1998; Schinke et al., 2011; Schinke et al. 2013) on being an immigrant athlete in host countries with their studies. They also examine the sport labour migration on variety of sports like soccer (Botelho \& Agergaard, 2011; Darby et al., 2007; Magee \& Sugden, 2002; Maguire \& Pearton, 2000; Maguire \& Stead, 1996a; Stead and Maguire, 2000), rugby (Kanemasu \& Molnar, 2012), handball (Agergaard, 2008), basketball (Banet-Weiser, 1999; Eastman \& Billings, 2001), African student athletes (Lee \& Opio, 2011). In sport labour migration studies soccer is the most attractive and lucrative sport in the world especially in European with their sport clubs and national teams. Because soccer is getting more attention, it is becoming more commercial when compared to other sports and has large number of migrant or immigrant sport labor.

A similar situation is observed, when compared with other sports in Turkey, soccer is more popular and commercialized and has the most migrant athletes. For example, the Turkish Super League was the $6^{\text {th }}$ most valuable brand in Europe (Pınar et al., 2017) and just more than half of the players (50,5\%) in Turkish Super League during the 2016-2017 season composed of immigrant athletes (Yüce et al., 2017). Although there is a great number of migrant athletes in Turkish Soccer Clubs, a limited number of studies have been conducted on specific facets, such as the "thoughts about the number of migrant athletes" (Yüce \& Balc1, 2018), and the "thoughts of Turkish athlete's on migrant athletes" (Doğan et al., 2004). It is obvious and interesting that we did not come across any studies conducted on motivators and problems of being an migrant athletes in Turkey, except a study on problems of women basketball players (Beşler et al., 2017).

This prelimanry study is important for the sports management students to explain the relationship between globalization and sports, and to understand emerging subjects that the motivators of migrant athletes and problems experienced by migrant athletes in the host country, as a result of globalization. Therefore, this preliminary study was designed to reveal the motivators while selecting the Turkey as the host country and problems of being a migrant sport labor in Turkish soccer clubs. Additionally, it will serve to guide the following studies on migrant sport labors' motivators and problems in different sports.

\section{Literature Review}

\subsection{Outsourcing in Sports}

The meaning of outsourcing is "providing the organization access to highly skilled and knowledgeable personnel often not available in-house and increased flexibility in conducting business." (Burden \& Lee, 2009). Outsourcing, which has been increasingly used since globalization has become more complex in the business world. Even though, the general business community has been using outsourcing as a corporate strategy for many years, outsourcing has become a more recent phenomenon in the sports industry (Burden \& Lee, 2009; Li \& Burden, 2002).

Outsourcing is often used in the sport industry as well as in many other industries as a strategic decision, because of its positive effects on organizational success. According to Lee (2016) there are two major outsourcing motivations: cost-driven and performance driven outsourcing. Cost-driven outsourcing is primarily based on cost reduction and aims to reduce indirect costs such as fewer employees. Performance-driven outsourcing approach is focused on the quality improvement perspective and expects to access expertise/resources and expects to develop professionally, such as acquiring knowledge through outsourcing.

The sports industry is actively adopting outsourcing strategies for similar purposes. Nowadays many sport organizations/clubs outsource such functions as advertising planning, human resource management, sponsorship relations, or webpage design. All of these operations for their marketing activities to handle merchandising, concessions, sales and customer service operations (Liu, 2011). Sport management literature shows that performance-driven outsourcing in terms of revenue maximization and the focus on core competencies are the primary motivations for outsourcing. (Lee, 2016). To maximize these marketing efforts, sports clubs use the outsourcing strategy for another purpose and gravitate towards the recruitment of talented immigrant labors for product quality: sporting success and game quality (Sherwin \& Sanderson, 2001). Because without sporting success and game quality, it is difficult to monitor globally, finding sponsors and advertisers, selling tickets and commercial products (merchandise).

Improving sporting success and game quality is highly dependent on talent of athletes. In sports, the competition for recruitment of talented athletes is getting more and more difficult internationally. As a result, resource access has become absolutely crucial (Lee, 2010). The migration of athletes usually follows likely paths. These paths are commonly referred to as 'talent/migratory pipelines' through which individuals can be recruited and channeled (Maguire \& Pearton, 2000; Molnar \& Maguire, 2008). At this point, the motivators to encourage talented athletes to 
emigrate from one place to another for keeping the pipelines open, becomes important. These motivators make it easier for athletes to emigrate from donor country to host country.

\subsection{Motivators of Sport Migrants}

After pioneers of studies in sport migration Bale and Maguire in 1994 (Bale \& Maguire, 1994), motivators for sports migrants were divided into five categories in a developed typology by Maguire in 1996 (Agergaard, 2008; Elliot \& Maguire, 2008). These five categories are pioneers, settlers, mercenaries, returnees and nomadic cosmopolitan. Magee and Sugden (2002) however criticized Maguires' typology of carrying inconsistencies and inaccuracies due to the lack of primary data to support the classifications. They presented six categories of sports migrants' motivators: the mercenary, the settler, the ambitious, the nomadic cosmopolitan, the exile and the expelled. The mercenary is an athlete who is motivated first and foremost by money. This type does not hesitate to move often to gain economic profit. The settler is an athlete who has moved to a host country as a sojourn. This type might even be motivated to stay in his host country after finishing his professional career for some benefits. The ambitious can also be considered as someone who has the desire to improve his career by moving to a better quality league. The nomadic cosmopolitan is an athlete, who is motivated to experience different cultures and nations. The exile is an athlete, who for sport-related, personal or political reasons leaves his country voluntarily or due to the threats to his career. The expelled is a player who is, in effect, forced to migrate. The player will have left his respective domestic leagues because a combination of behavior problems and high media exposure, which made it almost impossible for him to play professionally in his domestic leagues (Agergaard, 2008; Borges et al., 2015; Magee \& Sugden, 2002).

These typologies show that the motivators and experiences of athletic migrants vary considerably and are contoured by a series of complex interdependent processes. It is clear that politics, history, economics, geography, and culture can be influential in determining the facilitators of athletic migrants and affecting the migration process. It should not, therefore, be forgotten that to base on athletic migrant movements as the result of any single causal factor (Elliot \& Maguire, 2008).

\subsection{Problems of Sport Migrants}

According to the studies, athletic labor migration can actualise on three levels; within nation states, between nation states within the same continent, or on a transcontinental level (Elliot \& Maguire, 2008; Maguire \& Pearton 2000). In all cases, sport labour migrants can run into some problems that severely restrict their professional and in social lives in their host countries (Molnar \& Maguire, 2008). Because when the migrant athletes are settled in a new country or new community as a resident or a sojourn, they also move away from their own society and old social relations. In the literature, sport labour migrants' problems have been grouped under three categories; those encountered (a) in a new community, (b) in a new culture, but outside of sport, and (c) in sport contexts (Schinke, et al., 2011).

Although problems are grouped into three categories, within each of the three categories are generally create similar problems in social and professional life of migrant athletes. The problems affect their lives in host countries regardless of whether the migrant athletes are amateur or professional (Schinke et al., 2011). In a new community problems, for example homesickness and social isolation (Lee \& Opio, 2011), loneliness (Maguire \& Stead 1996b; Molnar \& Maguire, 2008; Evans \& Stead, 2014) and the loss of social ties affects athletes also in a sport context. Some of the migrant athletes find a way to overcome these types of problems before choosing the host country; South American athletic migrants prefer Spain and Portugal due to cultural similarity (Maguire \& Pearton 2000).

There are so many problems in a new culture outside of sport; clothing, meals, language (Battochio, et al. 2013; Schinke et al., 2011; Evans \& Stead, 2014; Kellerman, et al., 2005, p.209), lifestyle (Maguire \& Pearton 2000), xenophobia (Molnar \& Maguire, 2008), religion (Portes \& DeWind 2010), nationalism and so on. Just as "in a new culture" problems, some problems of "outside of sport" like language can also effect "in-sport context" life. In fact, some of the sports migrants, do not want to face this problem and give a special care to prefer same language spoken countries: for example French-Canadian ice hockey players are choosing French speaking countries (Elliot \& Maguire, 2008).

The problems of migrant athletic labour in sport context can be explained under a heading of integration. The multinational character of most of professional soccer clubs naturally increases certain problems of integration with migrant players' on a new team (Kellerman et al., 2005, p. 211). The integration problems may consist of: fitting in with a new team, adapting to new coaching staff and coaching style (Schinke et al., 2011) and adjusting the team mates. For example, migrant players can encounter disrespectfully behaviours from local players and local players can perceive migrant players as a threat, or persons who take their jobs and positions away (Molnar \& Maguire, 2008). In addition to integration problems, there are inherently several problems like organizational communications and legal issues (Lee, 2010). After 1995 Bosman ruling (Steinberg et al., 2013) is seriously decimated legal issues in soccer, so players and coaches are usually the prevailing party in legal issues. For example, some of the migrant athletes and coaches have initiated legal proceedings in Turkey and have won lawsuits against their clubs (Sabah, 2016). 


\subsection{Soccer and Soccer Migrant Labor in Turkey}

Turkey is a country that holds the thirty-eighth rank in the FIFA world rankings (FIFA, 2018), and the tenth in UEFA ranking (Kassiesa, 2018), and the four Turkish soccer clubs in UEFA's first 100 lists (UEFA, 2018). Soccer is the most popular, only commercialized and professional sport in Turkey. Turkey is usually called as a "soccer country" or a country "in love with soccer" (Yılg1, 2018; Genç, 2017). This is because 52.7\% of Turkish people use the word "soccer" synonymously with the word 'sport' (Turkish Football Federation, 2005:25). Furthermore, 69\% of columnists and sport correspondents cover soccer news (Illhan, 2004:66), media coverage of soccer is considerably higher (\%73) than other sports in print media (Uzun, 2001:173). Sport programs on visual media are largely dominated by soccer (Cerrahoğlu, 2004), as half of total Turkish athletes are licensed in soccer (SGM, 2017) and as mentioned before Turkish Super League was the sixth most valuable brand in Europe (Deloitte, 2018).

In addition, Turkey is a European country (not EU member) that continents Asia and Europa, and is quite close to Africa. As the Maguire and Pearton (2000) stated the movement of sports labour on a trans-continental level occurs between Europe and Africa. Turkey is also in close proximity to the former 'Iron Curtain' nations (most of the soccer labours migrates to Western Europe) and Africa, and Turkish soccer clubs generally use these pipe lines for employing the migrant soccer labor (Doğan et al., 2004). All reasons above and arguably for geo-cultural reasons, Turkey becomes an attractive destination for migrant soccer labours (Habertürk, 2010).

In studies related to migrant athletes, migrant athletes provide some advantages like better quality of team performance, with foreign players improving the standards of existing players and also acting as a role model for younger players (Magiure \& Pearton, 2000) and to enhance the marketing efforts (Burden \& Li, 2009; Lee, 2016; Li \& Burden, 2002; Liu, 2011). Turkish soccer clubs employ the migrant athletes of course for the same motives. For example legendary chairman of Fenerbahçe Aziz Yıldırım mentioned "higher media exposure of Fenerbahçe team internationally after employing Roberto Carlos" (Yıldırım, 2008:39), and Aykut Kocaman one of the famous Turkish trainer stated that "migrant players are chepar than the local players" (Yıldırım et al., 2012).

\subsection{State of Migrant Soccer Labour in Turkey}

The first migrant sport labor in Turkey Billy Hunter worked as a coach for the Turkish National Soccer Team between the years of 1924-1926 and at the same time Galatasaray Soccer Team between the years of 1924-1928 (Irak, 2013). The migration of athletes in soccer had been coming into sight in 1951, just after professionalism of soccer in Turkey (Yüce \& Balc1, 2018). The pioneer of migrant soccer labor was Oscar Garo from Argentina (Gören, 2017). Turkish Football Federation (TFF) however, was limited by the number of migrant athletes in the beginning and have changed limitation rules often since 2000 (Table I).

Table I. Migrant Player Limitation System of Turkish Football Federation

\begin{tabular}{llllll}
\hline Season & TFF LS & PC & Substitute & GL & In Deal \\
\hline $1951-1966$ & 1 player & 1 player & 1 player & 1 player & 1 player \\
$1966-1989$ & 2 players & 2 players & 2 players & 2 players & 2 players \\
$1989-1996$ & 3 players & 3 players & 3 players & 3 players & 3 players \\
$1996-2000$ & $3+1$ players & 3 players & 1 players & 4 players & 4 players \\
$2000-2001$ & $5+1$ players & 5 players & 1 players & 6 players & 6 players \\
$2001-2005$ & $5+1+2$ players & 5 players & 1 players & 6 players & 8 players \\
$2005-2007$ & 6 players & 6 players & 6 players & 6 players & 6 players \\
$2007-2008$ & $6+1$ players & 6 players & 1 players & 7 players & 7 players \\
$2008-2010$ & $6+2$ players & 6 players & 2players & 8 players & 8 players \\
$2010-2011$ & $6+2+2$ players & 6 players & 2players & 8 players & 10 players \\
$2011-2013$ & $6+2$ players & 6 players & 2 players & 8 players & NL \\
$2013-2014$ & $6+0+4$ & 6 players & 6 players & 6 players & 10 players \\
$2014-2015$ & $5+3$ & 5 players & 3 players & 8 players & 8 players \\
$2015-2018$ & NL & NL & NL & NL & NL \\
\hline
\end{tabular}

LS: Limitation System, PC: Play in Court, GL: Game List, NL: No Limitation

Reference: Yüce et al., 2017; TFF, 2016; TFF, 2017; Futbol Arena, 2015. 
It is evident that the limitation on migrant athletes steadily declined over the years, which is now abolished since 2015. Also, the percentage of migrant players sharply increased after that time (Table II). After abolishing the limitation of migrant athletes, Galatasaray Soccer Team broke a new ground in Turkish soccer and started the game with 11 migrant players versus Atiker Konya Sport in 14 September 2017 (Sputniknews, 2017).

Table II. Number and \% of Migrant Players (some selected seasons before 2000)

\begin{tabular}{llllll}
\hline Season & TNP/MP & \% of MP & Season & TP/MP & \% of MP \\
\hline $2017-2018$ & $475 / 247$ & 52.0 & $2005-2006$ & $551 / 135$ & 24.5 \\
$2016-2017$ & $703 / 297$ & 42.2 & $2004-2005$ & $548 / 122$ & 22.3 \\
$2015-2016$ & $671 / 255$ & 38.0 & $2003-2004$ & $493 / 112$ & 22.7 \\
$2014-2015$ & $623 / 200$ & 32.1 & $2002-2003$ & $459 / 109$ & 23.7 \\
$2013-2014$ & $708 / 229$ & 32.3 & $2001-2002$ & $426 / 114$ & 26.7 \\
$2012-2013$ & $631 / 211$ & 33.4 & $2000-2001$ & $418 / 103$ & 24.6 \\
$2011-2012$ & $588 / 200$ & 34.0 & $1998-1999$ & $366 / 82$ & 22.4 \\
$2010-2011$ & $643 / 205$ & 31.8 & $1995-1996$ & $320 / 56$ & 17.5 \\
$2009-2010$ & $668 / 188$ & 28.1 & $1993-1994$ & $288 / 53$ & 18.4 \\
$2008-2009$ & $513 / 144$ & 28.1 & $1992-1993$ & $313 / 49$ & 15.6 \\
$2007-2008$ & $550 / 140$ & 25.5 & $1990-1991$ & $389 / 53$ & 13.6 \\
$2006-2007$ & $492 / 128$ & 26.0 & $1986-1987$ & $246 / 18$ & 7.3 \\
\hline
\end{tabular}

TNP: Total Number of Player, MP: Migrant Player

Reference: Transfermarkt, $86 / 87$ to $17 / 18$ seasons.

Taxation is the fundamental tool to meet the social needs of citizens for nation states and also important issue for migrant sport labor as well. The income of athletes is also recognized as revenue in accordance with laws, whether they are an immigrant or not. Sport and athletes are conserved under in by law of the Turkish Republic, because of positive impact on community life. The Turkish government provides some concessions on income taxation both professional and amateur athletes. According to the Income Tax Laws' Temporary Article 72, income tax of athletes as follows (Gelir Vergisi Kanunu, 2008):

- $5 \%$ for third or lower division

- $10 \%$ for second division

- $15 \%$ for first division

In league of Big Five (England, Germany, Spain, France and Italy), professional soccer players are pay income tax at a much higher rate than Turkey. For example (Öz and Akçay, 2013):

- More than three times in England

- More than almost three times in France

- More than three and a half times in Spain

- More than the three times in Germany

- Just more than three times in Italy

\section{Method}

This study is a qualitative research in terms of the data collection and analysis techniques. Interview method that is the most common form of communication based on dialog (Yıldırım and Şimşek, 2006:120), was used in this study.

\subsection{Participants}

Participants of this study were determined by nonrandom sampling techniques; convenience sampling and criterion sampling, which is one of the purposive sampling design (Etikan et al., 2016; Palinkas et al., 2015). The combinations of these sampling strategies are more appropriate to the aims of implementation of this research and are more consistent with latest developments in quantitative methods (Palinkas et al., 2015). When determining the sample of this study, easily accessible first division soccer team (Turkish Super League) Ankara Genclerbirligi was selected and eight migrant male athletes of Gençlerbirliği were determined as participants according to two criterions: being a migrant 
athlete at least in two different countries before transferred to the Turkish soccer clubs and playing at least one season in the Turkish Super League.

\subsection{Procedures}

The purpose of this study was explained to participants verbally by professional translators of Genclerbirligi team, and confidentiality and privacy was guaranteed to them. Interviews were performed face to face 'before or after training sessions' by taking beforehand date of appointment, between in May 1-15 2018. All interviews were recorded by using audio and video recording devices.

\subsection{Data Collection Tool}

This study involved demographic information form and semi-structured interview form that is a qualitative research data collection technique. Following stages were taken to develop the interview form; previous studies and research were analyzed to establish a framework first, second, according to framework ten items semi structured interview form was composed, and third, consultations with two academicians were qualified in sport sociology and one academician in qualitative research, and with two migrant athletes.

After these steps, the interview form was composed of nine items. Two items related to the general ideas of athletes before and after migration to Turkey, five items were relevant to motivators of migration to Turkey, and two items were associated with problems in sport context and outside of sport life.

\subsection{Data Analysis}

In this study, data obtained from face-to-face interviews was analyzed by content analysis. To ensure the reliability and the validity of the research, data gathering and analysis methods were explained in detail, data was recorded by audio and video devices, one professional translator (soccer team employee) and at least two researchers participated in the interviews, direct quotations were given coverage to in the results, and expert opinions were offered for consideration.

\section{Results}

Table III. Demographics of Participants

\begin{tabular}{clccc}
\hline AGE & NP & PE & PME & ET \\
\hline 26 & France & 10 & 2 & 3 \\
26 & Brazil & 8 & 2 & 2 \\
30 & Sweden & 11 & 2 & 3 \\
27 & Brazil & 9 & 5 & 1 \\
24 & Nederland & 6 & 3 & 1 \\
28 & Belarus & 11 & 3 & 1 \\
28 & France & 11 & 3 & 3 \\
30 & Serbia & 12 & 2 & 1 \\
\hline
\end{tabular}

Nationality of Participants (NP), Player Experience in Year (PE), Previous Migrant Experience in Number (PME), Experience in Turkey in season (ET)

The participants that took part in this study, were between 26 and 30 years old, their experience as a professional soccer player was varied between 6 and 12 years, previous migrant experience was ranged from 2 different countries to 5 different countries and their experience in Turkey was changing between 1 season to 3 seasons.

\subsection{Motivators of Migrant Soccer Labour in Turkey}

Almost all of the participants of this study (seven in total), considered themselves as a "mercenary migrant". Because, they expressed that "financial incentives" was the primary motivator for them to play soccer in Turkey. Moreover, the participants of P1, P3, P4, P5 and P7 described their thoughts very precisely and briefly: They just said "Money". Two participants out of eight only described their thoughts a little bit more in detail. "I left my country for the money. Because the offered price in my country was much lower than in Turkey. Therefore, I thought that the offer from the Turkish club was more attractive than the others. In addition, my club was provided me some additional benefits"(P6). Another participant said that, "... financial issues is important in professional soccer. Turkish Soccer clubs pay satisfactory level of transfer fees. Therefore, I chose Turkey "(P2).

The findings of the study was showed that the selection of Turkish Super League by migrant soccer players (four players) were depended on two reasons: quality of league and convenience for career development. Ambitiousness, 
however was their secondary motivator for all three participants. One of these participants has identified himself primarily as "nomadic cosmopolitan" and the others as "mercenary". During the decision making process, participants have gathered the information from their friends on whether the Turkish super league is proper for their career development or not. Their friends from the same nation who played soccer in Turkey before, and Turkish immigrants that were playing soccer in their home country, constituted the sources of information. Positive feedbacks regarding the Turkish Super League, prompted them to start their journey to Turkey as a migrant soccer player.

Participants expressed their opinions on this subject as follows; "I was already following the Turkish Super League, before a job was offered by the Turkish Soccer club. I have also Turkish friends that have immigrated with their families, and they were playing soccer in my country. According to the feedback that I got from them, I thought, Turkish Super League is really a quality league and it could be made my career positive contribution" (P8). "I have Turkish friends, playing soccer in the Netherlands. I got information from them. The information I received, Turkey is a good country and quality soccer was played in Turkish Super League. After living for a while in Turkey, I would say the same things. Turkish league is a very enjoyable" (P5).

Only one of the participant was stated, the reason of playing soccer in Turkey was that desire to live in different culture and country. "I was playing soccer in my country, before coming to Turkey. But I also knew that playing soccer abroad is important for every player. You know, go through the changes in life is sometimes good. Different people, a different culture." (P2).

\subsection{Problems of Migrant Soccer Labour in Turkey}

Problems in Sport Context: The main problem expressed by migrant players in general, was difficulties with coaches. It can be said that, making comparison between Turkish coaches and the other coaches that they have worked together before impacted their decisions. The main concern is the tactical understanding of the Turkish coaches. For example, P1 expressed his perception "I had problems when I was came to Turkey. It was not easy for me especially in tactical aspects". The other participant (P8) said that "... for Turkish coaches tactical trainings were moving ahead of the other important elements of soccer." Participants was emphasized the differences in training and tactical understanding as a sport context problem.

Some of the participants mentioned the human relation problems, between the players and the coaches. Participant (P1) was commented on his considerations: "In my country, coaches behave more friendly towards the players. They try to communicate with all players, whether they take part in the team/game or not. Another participant (P5) indicated that "Turkish coaches do not understand the feelings of the player at all ... they regard players as a machine and they do not talk with us about our problems".

The findings of the research was showed that the human relation problems arise from the display of autocratic leadership behaviors of Turkish coaches. For example, participant P3 "There is widening gulf between coaching styles in Sweden and in Turkey. Here (in Turkey) coaches are autocratic but in Sweden they are more like friends. Coaches conduct the meeting once a week in Sweden to get the opinions of players. In Turkey, the coaches take the decisions by themselves". In final, this study underlined human relations problem as it correlates with the autocratic leadership behaviors of Turkish coaches.

Problems in out of Sport Context: The most striking problem for migrant players were encountered outside of sport life was the language. The migrant players stated that they could not get into the social life because of language barrier. For example; "language is the biggest problem in Turkey. I do not speak in Turkish, Turkish players in my team or other people around us couldn't speak another language, so that I do not get into the social life so much." (P6). For this reason almost all of the participants have been stressed that, they prefer to spend their free time with migrant players or with their family members. The opinions of participants' on this issue are as follows: "I spend most of my spare time with migrant players, because I don't have a language problem while communicating with them" (P7). "I spend most of my leisure time with my family"(P8).

Other problems that were encountered by participants in social life, was caused by disrespectful behaviors of Turkish people in general. "Turkish people do not behave much more respectful to each other. You can feel this in everywhere; in the bank, on the traffic, in the shopping center, even waiting the elevator" (P6). "I have a lot of problems while I am driving in traffic or when crossing the road while I am walking. Because Turkish people drive their cars quite differently. People are not very respectful in traffic "(P3). The participants observed that people live in an unplanned way in Turkey and perceived this as a threat to their own lifestyles. "...people live like "take each day as it comes" in here. This situation is present in business life as well. In my country people live more organized and planned manner. The difference in lifestyle make it difficult for us to adapt to Turkey. "(P3). 


\section{Discussion}

In recent decades, Turkey has come off as a crucial destination of immigration (Tolay, 2012). The similar situation seen in sports fields, particularly in professional soccer and the number of foreign players in the Turkish Super League has quadrupled over the past 20 years (see in table II). Of course, some of the reasons have an effect on the increasing number of foreign migration of athletes. For example, disinhibition of the foreign player limitation by TFF in time, Turkish soccer clubs prefer foreign athletes because of their lower costs, except highly talented and famous ones (Yıldırım et al., 2012), effects of outsourcing by globalization on Turkish soccer clubs, and "motivators" that the focus of our study, cause soccer players to travel to Turkey as a host country.

Naturally, not only one motivator is impactful on migration of athletes, and typologies that explain the motivators, are grouped under five or six items (Bale \& Maguire, 1994; Magee \& Sugden, 2002). Three of these items were found in our study (Table II): mercenary (7 athletes), ambitious (4 athletes) and nomadic cosmopolitan (1 athlete). Although athletes migrate for one or more than one reason, studies shows that money is an important motivators for most of the migrant athletes (Agergaard, 2008; Molnar \& Maguire 2008; Reiche, 2015; Stead \& Maguire, 2000), like in our study.

In these condition, we can say that if migrant athletes want to play in Europe and in a quality league, and their priority is to make money, Turkey is one of the best countries to be preferred for them. Because Turkey is called a "tax haven country" for professional and amateur athletes (Öz \& Akçay, 2013; Köprü, 2016, Cnn Turk, 2017). Many of the migrant soccer labours put a clause in their contracts for payment of their tax debts by the soccer clubs, especially the most talented and famous soccer players that are coming to the end of their career paths, like Wesley Sneijder, Robin Van Persie, Mario Gómez, Samuel Eto'o (Karabıyı, 2016). Resultantly, migrant athletes have a strong chance to double their income in Turkey. Participants of this study are also aware of this situation, even if they did not clearly stated during the interviews. So, we can say that, it is quite natural to choose Turkey as a host country by the mercenary athletes.

Choosing Turkey as a host country for migrant soccer players of this study was, to continue their career development in a quality league. Since the Turkish Super league's taking sixth place in European leagues and Turkish teams' ranking among in top 100 or top 200 soccer teams of the European team ranking, makes Turkey desirable host country for migrant soccer players. In this study four participants, already identified themselves as ambitious, also stressed that Turkey was really a quality league. For example, P7 "Turkey is a beautiful country and quality of soccer is quite similar to France" and P4 "before coming to Turkey I heard that, wages of players' was not paid or was paid late by some of the soccer clubs. But I already knew that the quality of the soccer was satisfactory level in Turkey". Although ambitiousness is recognized as one of the most important motivator in selection of a host country by migrant athletes in the literature (Badilla, 2017), being a transitional athlete for ambitious purpose came after mercenary purpose for the participants of this study.

The studies in the literature, there is a number of migrant athletes, have identified themselves as a "nomadic cosmopolitan" (Agergaard, 2008; Borges et al., 2015; Shor \& Yonay, 2010). In this study also, one participant out of eight participants classified himself as a nomadic cosmopolitan. Opinions of some participants about Turkey except P2, are as follows: "I am a Muslim. So that, I easily get used to this country where most of its citizens are Muslims." P1; "I had no knowledge, before I was coming to Turkey. It is a beautiful and huge country. It's so funny to play soccer and to live, in Turkey." P8. As is seen, thoughts of the participants' about Turkey is generally favorable. Because, Turkey is a country where, many of civilizations dawn in history, connecting the continents of Asia and Europe and although majority of people is Muslims, has multi-religious structure like Judaism, Yezidism, and Christianity-Assyrians. Due to its own characteristics, many different cultures are still living friendly in Turkey (Tanrikulu, 2015; Tutar Serter, 2017; Yüce, 2014). Therefore, it can be said that, Turkey is a quite favorable place for migrant athletes, who want to live or to understand different cultures.

For this study, the most important problems emerged in a sports context were in human relations between coaches and athletes, and the coaches decision-making processes. Whereas, this situation is take place due to difference between western societies and eastern societies on management mentality. Because, common mind is mostly used in decision making in western societies, whereas eastern societies are more paternalist and prefer to follow the leaders in the decision-making process (Köksal, 2011). So, this problem that was encountered by the participants in human relations, is related to being in a different culture. Another problem, in the sport context was perceived in the training methods of coaches. Participants argued for more tactical trainings, instead of developing technical skills. The thoughts of migrant players on this subject are quite natural. Because, it is almost impossible to perform the tactics in the game without developing technical skills (Etnier, 2009:24). The main reasons for these findings are as follows; Turkish coaches are mostly former professional soccer players, and thus have limited academic knowledge of the training science. They also have recently come to understand the importance of training science. 
The language problem was the most important problem that migrant athletes encounter out of sports context. In literature, frequently emphasized that problem of language is the most important problem for migrant athletes (Lee \& Opio, 2011; Kellerman et al., 2005; Molnar \& Maguire, 2008; Schinke et al., 2011). To overcome this problem while deciding a host country, migrant athletes select the countries that either speak the same language (Elliot \& Maguire, 2008) or countries where friends were migrated before from their home country (Molnar \& Maguire, 2008). The decreasing the effects of language problem helps facilitate the adaptation process and success of athletes (Kellerman et al., 2005). For example, "My team, has many migrant players from France or speaking in French. For this reason, I could easily adapt to Turkey and my team. I feel myself as, I 'm nearly playing soccer in my country" (P7). Language is also important problem in shaping friendships or relationships within the team and on feeling of loneliness. Participants' thoughts on this issue supports this opinion; P2 "I can't speak any other language except my mother language. So that, I can't enter into a dialogue with my teammates too much and I spend my leisure time generally resting alone."; P4 "I usually spend spare time with my Brazilian friend, he suffered through loneliness before I come, because he can't speak English or another language also."; P5 "I have good connections with Turkish players, but I usually spend time with foreign players in the club. Especially with African players ".

Lifestyle differences and human relations were the other problem encountered by migrant athletes beside the language in outside life. Differences in life style (Maguire \& Stead, 1996b; Maguire \& Pearton, 2000; Schinke et al., 2011) and human relations can be seen also in some studies, as problems. In this study, the unplanned life of the Turkish people was considered as problem, by migrant players. In fact, this difference originates from the lifestyles of western and eastern societies (Özçelik, 2015; Yılmaz, 2017). Because, western societies like planning their life in general, while eastern societies are not accustomed to planned life, except the educated ones. Another problem has emerged in human relations. This problem can be grouped under two headings; honesty and respect. For example, P1 "Some of the taxi drivers make longer the destination for getting more money when they realize we are foreigners. You can also be faced abnormal bills in restaurants "; K7 "I had problems with the car rental companies and with my landlord. They were tried to get more money, or they said that, "you have to do implement the some procedures", although that were their own responsibilities. Because I'm a professional soccer player". Four participants of this study mentioned two types of problems in their outside life and the other four participants (P2, P4, P5, and P8) however stated that they did not encounter any problems.

\section{Conclusion}

This preliminary study that supported the "mercenary", "ambiotis" and "nomadic cosmopolitan" items in the typologies that motivates the athletes to migrate a host country, carried out with professional soccer players who were temporarily migrating to Turkey. This research also revealed a facilitator that does not involved in typologies, but encourages participants to be a migrant soccer labour in a host country, this facilitator is "positive information".

This study also has found out that the problems encountered by migrant athletes are mainly due to the cultural differences between the eastern and western societies. For this reason, it can be said that athletes may have to get adequate knowledge about the cultural structure of that country before deciding to migrate to a host country. This knowledge may be useful for migrant labour athletes in predicting the problems that they are going to have and will make it easier for migrant athletes to cope with the adaptation problems that will be experienced in sport context life and life of outside sport.

The one of the limitations of this research is that, is directed to only a sports branch (soccer) and the other is that, is composed of migrant players of just a soccer club. The recommendations for the further studies are as follows; might explore the gender differences, various sports branches should be examined, can be included different sport clubs.

\section{References}

Agergaard, S. (2008). Elite athletes as migrants in Danish women's handball. Internatıonal Review for the Sociology of Sport, 43(1), 5-19. https://doi.org/10.1177/1012690208093471

Armstrong, M. (2018). The football clubs with the most foreign-bought players [Online], 23 January. Available from: https://www.statista.com, [Accessed 17 May 2018].

Badilla, I. C. (2017). Sport migration in Costa Rica: Motivations and goals of athletes' outflow. Seoul National University Dissertation. [Online]. Available from; http://s-space.snu.ac.kr, [Accessed 18 May 2018].

Bale, J., \& Maguire, J. (1994). Sports labour migration in the global arena, in J. Bale and J. Maguire (Ed) The global sports arena: athletic talent migration in an interdependent world, chapter 1, pp. 1-21. (Reprint 2003-1994), London: Frank Cass Publishers. [Online]. Available from; https://books.google.com.tr/books, [Accessed 25 June 2018].

Banet-Weiser, S. (1999). Hoop dreams. Professional basketball and the politics of race and gender. Journal of Sport and 
Social Issues, 23(4), 403-420. https://doi.org/10.1177/0193723599234004

Battochio, R. C., Schinke, R. J., McGannon, K. R., Tenenbaum, G., Yukelson, D., \& Crowder, T. (2013). Understanding immigrated professional athletes' support networks during post-relocation adaptation through media data. International Journal of Sport and Exercise Psychology, 11(1), 101-116. https://doi.org/10.1080/1612197X.2013.748996

Beşler, H. K., Engin, S. G., \& Çelik, V. O. (2017). Afro-American's life in Turkey: A study on woman basketball players, 15th International Sport Science Congress, 15-18 November 2017, Lara/Antalya/ Turkey, pp. 1592-1593.

Borges, M., Rosado, A., Oliveira, R., \& Freitas, F. (2015). Coaches' migration: a qualitative analysis of recruitment, motivations and experiences. Leisure Studies, 34(5), 588-602. https://doi.org/10.1080/02614367.2014.939988

Botelho, V. L., \& Agergaard, S. (2011). Moving for the love of the game? International migration of female footballers into Scandinavian countries. Soccer and Society, 12(6), 806-819. https://doi.org/10.1080/14660970.2011.609681

Burden, W., \& Li, M. (2009). Minor league baseball: exploring the growing interest in outsourced sport marketing. Sport Marketing Quarterly, 18, 139-149.

Campbell, R. (2010). Staging globalization for national projects: Global sport markets and elite athletic transnational labour in Qatar, International Review for the Sociology of Sport, 46(1), 45-60. https://doi.org/10.1177/1012690210368887

Cerrahoğlu, N. (2004). Türkiye'de spor gazeteciliğinin imajı [Sport media image in Turkey]. Gazi Üniversitesi İletişim Fakültesi Dergisi, 19: 21-44.

Çimen, Z., Ötkan, C. Ç., \& Ulun, C. (2018). An attention grabbing sports organization with marketing strategies: NBA. International Congress on Recreation and Sport Management, 10-13 May, Bodrum/Turkey. pp. 335-336.

Cnn, T. (2017). Türkiye futbolda vergi cenneti [Turkey is a tax haven in football]. [Online] 03 March. Available from: https://www.cnnturk.com, [Accessed 10 August 2018].

Darby, P., Akindes, G., \& Kirwin, M. (2007). Football academies and the migration of African football labor to Europe. Journal of Sport and Social Issues, 31(2), 143-161. https://doi.org/10.1177/0193723507300481

Deloitte (2018). Annual review of football finance 2018 [Online]. Available from; https://www2.deloitte.com, [Accessed 25 April 2018].

Doğan, M., Doğan, A., \& Serbest, M. (2004). A research on the opinions of the professional Turkish football players of foreign players in super league. Atatürk University Journal of Physical Education and Sport Science, 6(1), 30-39.

Eastman, S. T., \& Billings, A. C. (2001). Biased voices of sports: Racial and gender stereotyping in college basketball announcing. Howard Journal of Communication, 12(4), 183-201. https://doi.org/10.1080/106461701753287714

Elliot, R., \& Maguire, J. (2008). Thinking outside of the box: Exploring a conceptual synthesis for research in the area of athletic labor migration. Sociology of Sport Journal, 25, 482-497. https://doi.org/10.1123/ssj.25.4.482

Etikan, I., Musa, S. A., \& Alkassim, R. S. (2016). Comparison of convenience sampling and purposive sampling. American Journal of Theoretical and Applied Statistics, 5(1), 1-4. https://doi.org/10.11648/j. ajtas.20160501.11

Etnier, L. J. (2009). Bring your "A" game: A young athlete's guide to mental toughness. The University of North Carolina Press. Chapel Hill.

Evans, A. B., \& Stead, D. E. (2014). 'It's a long way to the Super League': The experiences of Australasian professional rugby league migrants in the United Kingdom. International Review for the Sociology of Sport, 49(6), 707-727. https://doi.org/10.1177/1012690212464700

FIFA (2018). FIFA/Coca-Cola world 'ranking-men' ranking. [Online] 07 June. Available from; https://www.fifa.com, [Accessed 23 July 2018].

Futbol, A. (2015). Yıllar itibariyle Türk futbolunda yabancı sınırlaması [Limitations of foreign players in Turkish football over the years]. [Online] 06 January. Available from; http://www.futbolarena.com, [Accessed May 2018].

Gelir, V. K. (2008). 5566 Sayılı Kanunun 8 inci maddesiyle eklenen geçici madde. Yürürlük: 01.07.2008. [Income Tax Law, provisional article added to Article 8 of Law No. 5766. Effective date: 01.07.2008]. [Online]. Available from; http://www.turkvergi.net, [Accessed 27 June 2018].

Genç, S. (2017). Spor politikamız değişmeli [Sport Policiy Must Change]. [Online] 04 May. Available from; https://www.yeniasir.com.tr, [Accessed 04 May 2018].

Gören, M. (2017). Nereye koşuyoruz? [Where are we running?]. Bütün Dünya Dergisi, Başkent Üniversitesi Kültür 
Yayını, 109-111. [Online] September 2017. Available from; http://www.butundunya.com, [Accessed 25 June 2018].

Habertürk (2010). Yabancı futbolcular Türkiye'yi neden tercih ediyor? [Why the foreign footballers are choosing Turkey?]. [Online] 30 March. Available from; https://www.haberturk.com, [Accessed 22 March 2018].

Hay, R. (1998). Croatia: Community, conflict and culture: The role of soccer clubs in migrant identity. Immigrants \& Minorities, 17(1), 49-66. https://doi.org/10.1080/02619288. 1998.9974928

İlhan, E. (2004). Türkiye'de spor muhabirlerinin iş problemleri [Occupational problems of sport reporters in Turkey]. Unpublished Master Thesis. Ankara (Turkey): Gazi University.

Irak, D. (2013). Hükmen yenik! Türkiye'de ve İngiltere'de futbolun sosya-politiği, [Defeated! The socio-political football in the UK and Turkey]. Evrensel Basım Yayın, İstanbul. [Online]. Available from; https://books.google.com.tr, [Accessed 18 May 2018].

Kanemasu, Y., \& Molnar, G. (2012). Pride of the people: Fijian rugby labour migration and collective identity. International Review for the Sociology of Sport, 48(6), 720-735. https://doi.org/10.1177/1012690212453655

Karabıyık, A. (2016). Van Persie, Gomez, Sneijder neden vergi ödemiyor, [Why Van Persie, Gomez, Sneijder do not pay taxes]. [Online] 27 January. Available from; http://www.hurriyet.com.tr, [Accessed 11 August 2018].

Kassiesa (2018). UEFA country ranking 2018. [Online] 22 March. Available from; https://kassiesa.home, [Accessed 25 July 2018].

Kellerman, E., Koonen, H., \& Haagen, M. (2005). "Feet speak louder than the tongue": A preliminary analysis of language provisions for foreign professional footballers in the Netherlands. Michael H. Long (Ed.), Second Language Needs Analysis, Cambridge University Press, pp. 200-217. New York.

https://doi.org/10.1017/CBO9780511667299.008

Köksal, O. (2011). Bir kültürel liderlik paradoksu: paternalizm [A cultural leadershıp paradox: paternalısm]. Mustafa Kemal University Journal of Social Sciences Institute, 8(15), $101-122$.

Köprü, F. M. (2016). Biraz da futbolun vergisi [A little about the tax of football]. [Online] 12 June. Available from; http://www.ekonomist.com.tr, [Accessed 11 August 2018].

Lee, J., \& Opio, T. (2011). Coming to America: Challenges and difficulties faced by African student athletes. Sport, Education and Society, 16(5), 629-644. https://doi.org/10.1080/13573322.2011.601144

Lee, S. (2010). Global outsourcing: a different approach to an understanding of sport labour migration. Global Business Review, 11(2), 153-165. https://doi.org/10.1177/097215091001100203

Lee, S. (2016). Economic view and strategic management view toward understanding outsourcing in amateur sport. Journal of Amateur Sport, Special Issue: Political Economy, 12-38. https://doi.org/10.17161/jas.v2i1.5019

Li, M., \& Burden, W. (2002), Outsourcing sport marketing operations by NCAA division I athletic programs: an exploratory study. Sport Marketing Quarterly, 11(4), 226-232.

Liu, Z. (2011). Marketing outsourcing of Chinese sports clubs: A swot-ahp analysis. Fourth International Conference on Business Intelligence and Financial Engineering, 169-174. [Online]. Available from; https://ieeexplore.ieee.org, [Accessed 09 August 2018].

Magee, J., \& Sugden, J. (2002). "The world at their feet" professional football and international labor migration. Journal of Sport \& Social Issues, 26(4), 421-437. https://doi.org/10.1177/0193732502238257

Maguire, J. \& Stead D. (1996a). Border crossing: Soccer labour migration and the European Union. International Review for the Sociology of Sport, 33(1), 59-73. https://doi.org/10.1177/101269098033001005

Maguire, J. (1996). Blade runners: Canadian migrants, ice hockey, and the global sports process. Journal of Sport and Social Issues, 20(3), 335-360. https://doi.org/10.1177/019372396020003007

Maguire, J., \& Pearton, R. (2000). The impact of elite labour migration on the identification, selection and development of European soccer players. Journal of Sports Sciences, 18, 759-769. https://doi.org/10.1080/02640410050120131

Maguire, J., \& Stead, D. (1996b). Far pavilions?: Cricket migrants, foreign sojourns an costended identities. International Review for Sociology of Sport, 31(1), 1-23. https://doi.org/10.1177/101269029603100101

Molnar, G., \& Maguire, J. (2008). Hungarian footballers on the move: Issues of and observations on the first migratory phase. Sport in Society, 11(1), 74-89. https://doi.org/10.1080/17430430701717798

Öz, E., \& Akçay, F. (2013). Futbolcular özelinde sporcuların vergilendirilmesi [Taxatıon of athletes in partıcular footballers]. Vergi Sorunları Dergisi, September, Number: 300, 35-54. 
Özçelik, T. G. (2015). Doğu ve batı dikotomisinin yarattığı gerçeklik: oryantalizm-oksidentalizm [The dıchotomy that created by east and west: orıentalısm and occidentalısm]. Internatıonal Journal of Eurasia Social Sciences, 6(19), June, 168-193.

Palinkas, L. A., Horwitz, S. M., Green, C. A., Wisdom, J. P., Duan, N., \& Hoagwood, K. (2015). Purposeful sampling for qualitative data collection and analysis in mixed method implementation research. Administration and Policy in Mental Health, 42(5), 533-544. https://doi.org/10.1007/ s10488-013-0528-y

Pınar, M., Nardalı, S., Alkibay, S., \& Girard, T. (2017). Türkiye Süper Ligi’nin marka değerini etkileyen faktörlerin öneminin ve performansının değerlendirilmesi. Pazarlama ve Pazarlama Araştırmaları Dergisi, 19, 103-122.

Portes, A., \& DeWind, J. (2010). A cross-atlantic dialogue: The progress of research and theory in the study of international migration, Alejandro Portes, and Josh DeWind (Ed.), Rethinking Migration New Theoritical and Emprical Perspectives, pp. 3-28. Berghahn Books, New York, Oxford, 2010. [Online]. Available from; https://books.google.com.tr, [Accessed 11 May 2018].

Reiche, D. (2015). Investing in sporting success as a domestic and foreign policy tool: the case of Qatar. International Journal of Sport Policy and Politics, 7(4), 489-504. https://doi.org/10.1080/19406940. 2014.966135

Sabah, (2016). Teknik adamlar için tazminat cenneti Türkiye, [Turkey is a tax haven for coaches] 17.08.2016. [Online]. Available from; https://www.sabah.com.tr, [Accessed 13 July 2018].

Schinke R. J., \& McGannon, K. R. (2014). The acculturation experiences of (and with) immigrant athletes. International Journal of Sport and Exercise Psychology, 12(1), 64-75. https://doi.org/10.1080/1612197X.2013.785093

Schinke, R. J., McGannon, K. R., Battochio, R. C., \& Wells, G. D. (2013). Acculturation in elite sport: a thematic analysis of immigrant athletes and coaches. Journal of Sports Sciences, 31(15), 1676-1686. https://doi.org/10.1080/02640414.2013.794949

Schinke, R. J., Yukelson, D., Bartolacci, G., Battochio, R. C., \& Johnstone, K. (2011). The challenges encountered by 1mmigrated elite athletes. Journal of Sport Psychology in Action, 2(1), 10-20. https://doi.org/10.1080/21520704.2011.556179

SGM (2017). Spor Genel Müdürlüğü: istatistikler [General Directorate of Sport: Statistics]. [Online]. Available from; http://sgm.gsb.gov.tr, [Accessed 22 July 2018].

Sherwin, R., \& Sanderson, A. (2001). Labour markets in professional sports. The Economic Journal, 47-68. [Online] February. Available from; https://onlinelibrary.wiley.com, [Accessed 09 August 2018].

Shor, E., \& Yonay, Y. (2010). Sport, national identity, and media discourse over foreign athletes in Israel. Nationalism and Ethnic Politics, 16, 483-503. https://doi.org/10.1080/13537113.2010.527239

Sputniknews (2017). Türkiye'de ilk kez bir takım, 11 yabancı futbolcuyla sahaya çıktı [This is the first time in Turkey, a team appeared in field with 11 foreign players]. [Online] 14 October. Available from; https://tr.sputniknews.com, [Accessed 09 July 2018].

Stead, D., \& Maguire, J. (2000). The motivation and objectives of Nordic/Scandinavian players in English League soccer. Journal of Sport and Social Issues, 24(1), 36-60. https://doi.org/10.1177/0193723500241004

Steinberg, J., Murray, S., \& Harris, D. (2013). "The Joy of Six: free transfers". 21 June 2013 The Guardian. Archived from the original on 13 July 2018. [Online]. Available from; https://www.theguardian.com. [Accessed 18 June 2018].

Tanrıkulu, M. (2015). Türkiye coğrafyasında genel kültür, alt kültür ve mozaik kültür [The geography of Turkey, general culture, sub-culture, and the cultural mosaic]. TÜCAUM VIII. Symposium Paper Book. [Online]. Available from; http://tucaum.ankara.edu.tr, [Accessed 24 March 2108].

TFF (2016). 2016-2017 sezonu spor toto süper lig müsabakaları statüsü, madde 2 [2016-2017 season, sport toto super league competition status: Item: 2.]. [Online]. Available from; http://www.tff.org.tr, [Accessed 18 May 2018].

TFF (2017). 2017-2018 süper lig İlhan Cavcav sezonu müsabakaları statüsü, madde 2 [2017-2018 super league İlhan Cavcav season competition status: Item: 2]. [Online]. Available from; http://www. tff.org.tr, [Accessed 18 May 2018].

Thibault, L. (2009). Globalization of sport: an inconvenient truth 1. Journal of Sport Management, 23, 1-20. https://doi.org/10.1123/jsm.23.1.1

Tolay, J. (2012). Discovering Immigration into Turkey: The emergence of a dynamic field. International Migration, 
53(6), 57-73. https://doi.org/10.1111/j.1468-2435.2012.00741.x

Transfermarkt, Clubs of the super lig 86/87 to clubs of the super lig17/18. [Online]. Available from; https://www.transfermarkt.co.uk, 1986 to 2017, [Accessed 19 June 2018].

Turkish Football Federation (2005). Futbol kamuoyu araştırması [Football public opinion research]. Sam Araştırma (Turkey), TFF Publication.

Tutar, S. Y. (2017). Kültürel kimlik inşasına bir örnek: süryani diasporası [an example of cultural 1dentıty constructıon: Assyrian diaspora]. The Journal of International Lingual, Social and Educational Sciences, 3(2), 87-96.

UEFA (2018). UEFA club coefficients. [Online]. Available from; https://www.uefa.com, [Accessed 11 August 2018].

Uzun, R. (2001). Türkiye'de spor medyası (1980-2000) [Sport media in Turkey (1980-2000)]. Unpublished PhD dissertation. Ankara (Turkey): Gazi University.

Yıldırım, A., \& Şimşek, H. (2006). Sosyal Bilimlerde Nitel Araştırma Yöntemleri. 6. Baskı [Qualitative research methods in the social sciences. $6^{\text {th }}$ ed.]. Ankara, Seçkin Yayınları.

Yıldırım, E. (2008). Profesyonel ligdeki yabancı futbolcuların, Türkiye'de futbol oynamalarına ilişkin, ekonomik, sosyal ve kültürel açıdan görüşleri ve yerli futbolcuların yabancı futbolculara bakış açıları [Determined the foreign football players economic, social and cultural views about playing football in the Turkish professional leagues and also determined the native footballers' opinions about the foreign football players]. Unpublished PhD Dissertation. Ankara (Turkey): Gazi University.

Yıldırım, E., Sezen M., Savucu, Y., \& Karataş Ö. (2012). Türkiye profesyonel futbol liglerinde oynayan yabancı futbolcuların ekonomik, sosyal ve kültürel açıdan görüşleri [Economic, social and cultural aspects of foreign footballers in the Turkish professional leagues]. Uluslararası Insan Bilimleri Dergisi, 9(1), 283-295.

Yılg1, F. A. (2018). Futbol sevgisi... [Love of Football]. Önce Vatan Gazetesi. [Online] 27 June. Available from; http://www.oncevatan.com.tr, [Accessed 02 July 2018].

Yılmaz, B. (2017). Doğu-batı iki farklı düşünme yöntemi ve xx. yüzyıl batı sanatında doğu etkileri [East-west two different thınkıng methods and xx. eastern effects on century west art]. The Journal of Academic Social Science, 5(47), June, 242-254. https://doi.org/10.16992/ASOS.12388

Yüce, A., \& Balc1, V. (2018). Alienation in Turkish football: The opinion of Turkish sport public about the number of foreign football players in Turkish football. The Online Journal of Recreation and Sport, 7(1), 55-76. https://doi.org/10.22282/ojrs.2018.29

Yüce, A., Katırcı, H., \& Kuzu, C. (2017). Foreign football player limit in Turkish football leagues and opinions of Turkish football players. CBU Journal of Physical Education and Sport Science, 12(2), 24-39.

Yüce, M. (2014). Türkiye'nin kimlikleri: din, dil, etnisite, milliyet, devlet ve medeniyet [Identities of Turkey: religion, language, ethnicity, nationality, state and civilization]. İstanbul Gelişim Üniversitesi Sosyal Bilimler Dergisi, 1(1), 173-178.

\section{Copyrights}

Copyright for this article is retained by the author(s), with first publication rights granted to the journal.

This is an open-access article distributed under the terms and conditions of the Creative Commons Attribution license which permits unrestricted use, distribution, and reproduction in any medium, provided the original work is properly cited. 